\title{
Effects of boron concentration on the microstructure, mechanical and tribological properties of powder-pack borided AISI 4140 steel
}

Luciana Leite Silveira ( $\sim$ luciana.Ilsilveira@gmail.com )

Pontifícia Universidade Católica do Paraná

Anderson G. M. Pukasiewicz

Gelson B. de Souza

Paulo Soares

Ricardo Diego Torres

\section{Research Article}

Keywords: surface hardening, boriding, mechanical behavior, scratch test, wear

Posted Date: February 4th, 2022

DOI: https://doi.org/10.21203/rs.3.rs-1280089/v1

License: (c) (i) This work is licensed under a Creative Commons Attribution 4.0 International License.

Read Full License 


\section{Abstract}

Three different boron amounts were used in this study to control the microstructure, mechanical, and tribological properties of borided cases on AISI 4140 steel. A single $\mathrm{Fe}_{2} \mathrm{~B}$ phase was observed for the lowest boron amount, while both $\mathrm{Fe}_{2} \mathrm{~B}$ and $\mathrm{FeB}$ phases were present on the other two boron compositions. The highest surface hardness was observed in the highest boron amount. The scratch tests revealed different cohesive failure mechanisms on the samples, such as arc and chevron tensile cracks, and even chipping was observed for all three-studied boron amounts; it appeared at lower applied loads for the highest boron amount, indicating a likely detachment of the fragile FeB layer. The borided layers presented abrasive wear during the ball-on-flat wear tests. Despite the lower specific wear rate, the surface damage was more severe in the sample with the highest boron amount, due to its brittleness, resulting in lower resistance to surface fatigue.

\section{Introduction}

Wear is one of the most common metal surface degradation mechanisms; there are several ways to promote wear mitigation, such as increasing the surface hardness. Boriding is a very effective surface hardening treatment, which is applied to various ferrous and non-ferrous materials [1]. The boriding process in steels involves heating the material in a range between 700 and $1000^{\circ} \mathrm{C}$, for 1 to 12 hours, in contact with a boriding medium such as a solid powder, slurry, liquid, or gas [1]. Boriding in steels generates layers with excellent adhesion [2], mainly due to its columnar morphology [3]. Besides, borided layers present high hardness and, consequently, good wear resistance [4-13]. One of the boriding challenges is to set the appropriate process parameters to obtain the proper microstructure to withstand a given wear environment.

Pack boriding methods present the simplest experimental setup, compared to the other boriding methods, but higher temperatures and longer treatment times are required [14]. Pack boriding has been recently studied in the boriding of titanium-based alloys [14-19], steel alloys [6-8, 10, 20-26], cobalt-base alloys $[9,27-31]$, and nickel-base alloys [32-34], and is usually performed using commercial powder mixtures, however, the pack boriding of steel and iron with different powder compositions was previously investigated $[2,10,17,19,26,35,36]$. The borided layers in carbon and alloyed steels usually have the $\mathrm{Fe}_{2} \mathrm{~B}$ single-phase or a two-phase morphology: $\mathrm{FeB}$ and $\mathrm{Fe}_{2} \mathrm{~B}$. The FeB phase is richer in boron; however, a single $\mathrm{Fe}_{2} \mathrm{~B}$ phase is more desirable since the $\mathrm{FeB}$, of higher hardness, is brittle [1].

One highly used commercial powder mixture consists of $\mathrm{B}_{4} \mathrm{C}, \mathrm{KBF}_{4}$, and $\mathrm{SiC}$ [1]. The mechanism of pack boriding of steels using $\mathrm{B}_{4} \mathrm{C}$ (boron source), $\mathrm{KBF}_{4}$ (activator), and $\mathrm{SiC}$ (diluent) occurs according to the following reactions [37]:

$$
\mathrm{KBF}_{4}(s) 530^{\circ} \mathrm{C} K F(s)+B F_{3}(g)
$$




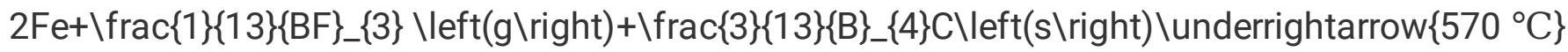
$\{F e\}_{-}\{2\} B+\backslash f r a c\{3\}\{52\}\{C F\}_{-}\{4\} \backslash$ left(g\right)+\frac $\{9\}\{52\} C \backslash$ left(s\right)

2

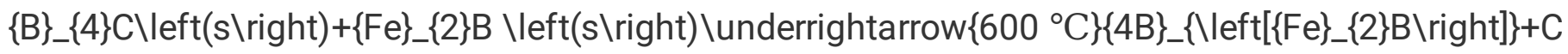
Vleft(s\right)

3

According to Martini et al. (2004) [38], the thermochemical growth of borides on iron can be described as a three-step mechanism. The first step is characterized by $\mathrm{Fe}_{2} \mathrm{~B}$ crystals growing on the metal surface, creating a layer with randomly oriented or locally-oriented (110) or (200) crystals. The second step is the $\mathrm{Fe}_{2} \mathrm{~B}$ crystals' growth towards the metal bulk, creating an inner and compact region, showing a (002) preferred orientation. $\mathrm{A}(002) \mathrm{Fe}_{2} \mathrm{~B}$ texture is established during the third step, and the needles grow perpendicular to the specimen's free surface [38]. The $\mathrm{Fe}_{2} \mathrm{~B}$ and $\mathrm{FeB}$ layers can form, but the free boron concentration on the steel surface dictate which of the following physicochemical processes will occur $[37,39]$ :

$\mathrm{B}+\mathrm{Fe} \backslash$ to $\mathrm{FeB}$, at theB/\{Fe\}_\{2\}Binterface

4

$\mathrm{B}+2 \mathrm{Fe} \backslash$ to $\{\mathrm{Fe}\}_{-}\{2\} \mathrm{B}$, at theB/\{Fe\}_\{2\}Binterface

5

$\{\mathrm{Fe}\}_{-}\{2\} \mathrm{B}+\mathrm{B} \backslash$ to $2 \mathrm{FeB}$, at theFeB/ $\left./ \mathrm{Fe}\right\}_{-}\{2\}$ Binterface

6

$\{2 \mathrm{Fe}+\mathrm{B} \backslash \text { to } \mathrm{Fe}\}_{-}\{2\} \mathrm{B}$, at the $\{\mathrm{Fe}\}_{-}\{2\} \mathrm{B} / \mathrm{Feinterface}(7)\{2 \mathrm{FeB} \backslash \text { to } \mathrm{Fe}\}_{-}\{2\} \mathrm{B}+\mathrm{B}$, phase transformation (8)

A lower boron concentration favors the $\mathrm{Fe}_{2} \mathrm{~B}$ formation, while a higher boron concentration enables FeB to form as well [37], as shown in Equations (4) and (6). The $\mathrm{FeB} \rightarrow \mathrm{Fe}_{2} \mathrm{~B}$ phase transformation (Equation 8) occurs by prolonging the boriding process under a boron depletion condition [37].

In the present work, the authors sought to perform the pack boriding of AISI 4140 steel with new easy to manufacture and repeatable boriding mixtures, to study the feasibility of controlling the microstructure, and, consequently, the mechanical properties and wear resistance of the material.

\section{Materials And Methods}

\subsection{Materials}

AISI 4140 steel (0.43 wt\% C, 1.00 wt\% Mn, 0.03 wt\% P, 0.04 wt\% S, 0.35 wt\% Si, 1.10 wt\% Cr, and 0.25 wt\% Mo) specimens were sectioned into $5 \mathrm{~mm}$ thick disc samples. These disc samples were prepared with 320 to 1200 grit $\mathrm{SiC}$ abrasive paper and rinsed with ethanol before the boriding process. A commercial boron mixture (Ekabor ${ }^{\circledR}$ ) consisting of $5 \mathrm{wt} \%$ of $\mathrm{B}_{4} \mathrm{C}, 5 \mathrm{wt} \%$ of $\mathrm{KBF}_{4}$, and $90 \mathrm{wt} \%$ of $\mathrm{SiC}$ was used as a basis for the development of two new boriding mixtures. The boron amount was varied by setting three amounts of $B_{4} C: 1,5$, and $10 w t \%$ yielding in 1.21, 4.35, and $8.26 w t \%$ of boron amount. Each of the three 
power mixtures contained $650 \mathrm{~g}$, and the amount of each reactant and the amount of boron in each powder mixture is shown in Table 1. Boron carbide $\left(\mathrm{B}_{4} \mathrm{C}\right)$ acts as a boron source, potassium tetrafluoroborate $\left(\mathrm{KBF}_{4}\right)$ as an activator of the boriding process, and silicon carbide $(\mathrm{SiC})$ as a diluent, not taking part in the chemical reaction of boriding.

Table 1

Powder composition of the boriding mixtures (wt\%).

\begin{tabular}{|llllllllll|}
\hline Sample & $\mathbf{B}_{\mathbf{4}} \mathbf{C}$ & \multicolumn{9}{c}{$\mathrm{KBF}_{\mathbf{4}}$} & & $\mathbf{S i C}$ & \\
\cline { 2 - 8 } & $\mathbf{w t} \%$ & $\mathbf{g}$ & $\mathbf{B}(\mathbf{g})$ & $\mathbf{w t} \%$ & $\mathbf{g}$ & $\mathbf{B}(\mathbf{g})$ & $\mathbf{w t} \%$ & $\mathbf{g}$ & \\
\hline $1.21 \mathrm{~B}$ & 1 & 6.5 & 5.09 & 5 & 32.5 & 2.80 & 95 & 611 & 1.21 \\
\hline $4.35 \mathrm{~B}$ & 5 & 32.5 & 25.45 & 5 & 32.5 & 2.80 & 90 & 585 & 4.35 \\
\hline $8.26 \mathrm{~B}$ & 10 & 65 & 50.90 & 5 & 32.5 & 2.80 & 85 & 552 & 8.26 \\
\hline
\end{tabular}

The $\mathrm{B}_{4} \mathrm{C}$ and $\mathrm{SiC}$ were supplied by Fiven Brazil, while $\mathrm{KBF}_{4}$ was acquired from Sigma Aldrich. The reactants of each boriding mixture, with a granulometry below $100 \mu \mathrm{m}$, were mixed in a Y-mixer for 2 hours at $31.5 \mathrm{rpm}$ on a lathe; and then mixed with $25 \mathrm{~mm}$ diameter alumina balls for 1 hour.

Subsequently, a portion of each powder mixture was placed in a steel container, enough to fill the container's bottom and create a $25 \mathrm{~mm}$ thick powder layer. Afterward, four-steel disc samples were placed in the container, then the rest of the container was filled with the powder mixture, after which the steel container was closed and placed in a furnace at $900^{\circ} \mathrm{C}$ for $2 \mathrm{~h}$. After the boriding process, the samples were air-cooled.

To facilitate the understanding of the manuscript, the AISI 4140 steel samples were identified according to the respective amount of boron in the powder mixture used in the pack boriding, as follows: 1.21B, 4.35B, and $8.26 \mathrm{~B}$.

\subsection{Characterization}

The borided specimens were prepared with 320 to 1200 grit SiC abrasive paper and polished with 0.25 $\mu \mathrm{m}$ diamond paste to a surface roughness of $\mathrm{Ra}<0.1 \mu \mathrm{m}$. Subsequently, the samples were etched with Nital $2 \%$. The microstructural features of the borided layers were determined through a specimens' crosssection inspection in a scanning electron microscope - SEM (Tescan Vega 3), allowing the examination of the morphology and the determination of the thicknesses of the borided cases. The average thickness of the $\mathrm{FeB}$ and $\mathrm{Fe}_{2} \mathrm{~B}$ layers was obtained by measuring 20 points in an SEM image with 2000x magnification. The thickness measurements consisted of establishing straight lines from the free surface to the ends of the peaks and valleys of the saw-tooth structure.

The identification of the phases in the borided layers was obtained through X-ray diffraction, XRD (Shimadzu XRD-7000) with CuKa radiation $\left(\lambda=1.54 \mathrm{~nm}\right.$ ), with thin-film setting using $2^{\circ}$ incidence angle, a scan speed of $0.5^{\circ} / \mathrm{min}$ and $0.02^{\circ}$ step, with a $2 \theta$ scan range from $35^{\circ}$ to $100^{\circ}$. 
The surface hardness $(\mathrm{H})$ was obtained by Vickers indentation, using a $250 \mathrm{mN}$ load and 15 seconds of indentation time. The reduced Young's moduli $(\mathrm{E})$ of the borided cases were extracted from the loaddisplacement curves using the method proposed by Oliver and Pharr [40], by instrumented indentation using a Berkovich indenter, following ASTM E2546-15 Standard [41], applying 24 steps up to a maximum load of $400 \mathrm{mN}$.

\subsection{Scratch adhesion tests}

The scratches were done and interpreted based on the ASTM C1624-05 Standard [42]. The scratch grooves were obtained in a Revetest Scratch Tester (Anton-Paar Instruments), with a Rockwell C diamond indenter with a tip radius of $200 \mu \mathrm{m}$. The test parameters were $398 \mathrm{~N} / \mathrm{min}$ loading rate, $6 \mathrm{~mm} / \mathrm{min}$ speed, progressive load from 1 to $200 \mathrm{~N}$, and a scratch length of $3 \mathrm{~mm}$. The scratch grooves were examined in a Tescan Vega 3 SEM to determine the failure mechanisms and to establish the critical loads $\left(L_{C}\right)$.

\subsection{Tribology tests}

The tribological tests were conducted using a ball-on-flat configuration of an Anton-Paar Instrument according to the ASTM G99-17 Standard [43]. The tribological pair counterpart was a $6 \mathrm{~mm}$ diameter alumina $\left(\mathrm{Al}_{2} \mathrm{O}_{3}\right)$ sphere. A sliding speed of $5 \mathrm{~cm} / \mathrm{s}$, a sliding track radius of $9 \mathrm{~mm}$, a constant load of 20 $\mathrm{N}$, and a sliding distance of $500 \mathrm{~m}$ were used for the tests. The coefficient of friction (CoF) was continuously recorded during the tests. After the tests, the wear tracks and their debris were analyzed by SEM/EDS (Tescan Vega 3) to determine the wear mechanisms during the tribotests and the chemical composition of the formed debris. An optical profiler (Taylor-Robson CCI Lite) was used to quantify the disk specimen wear, by measuring the cross-sectional area of the disk wear track. The average wear track area was multiplied by the wear track perimeter to obtain the total volumetric wear. The following equation determined the specific wear rate $(\mathrm{k})$ :

$\backslash$ kappa $=\backslash$ frac $\{$ V $\}\{F . L\}(9)$

where $V\left[\mathrm{~mm}^{3}\right]$ is the total volumetric wear, $\mathrm{F}[\mathrm{N}]$ is the normal load, and $\mathrm{L}[\mathrm{m}]$ is the sliding distance [44].

The wear of the alumina ball counter body was inspected by SEM/EDS (Tescan Vega 3) and optical profiler (Taylor-Robson CCI Lite).

\section{Results And Discussions}

\subsection{Morphology and surface properties}

The XRD diffraction patterns, shown in Fig. 1, reveal that the lowest boron amount (1.21B specimen) presented only peaks corresponding to the $\mathrm{Fe}_{2} \mathrm{~B}$ phase. In contrast, for the $4.35 \mathrm{~B}$ and $8.26 \mathrm{~B}$ specimens, the diffraction peaks of the $\mathrm{FeB}$ phase appear along with the diffraction peaks of the $\mathrm{Fe}_{2} \mathrm{~B}$, due to $\mathrm{a}$ higher concentration of free boron that enabled the FeB formation [37] by the physicochemical processes shown in Equations (4) and (6) [39]. 
The SEM images of the three borided conditions are in Fig. 2. The microstructures show a typical sawtooth morphology. The $\mathrm{Fe}_{2} \mathrm{~B}$ needles grow toward the substrate in the three conditions, with a (002) texture. The preferred orientation for all samples follows a path of minimum resistance in the [001] direction, which is normal to the substrate surface, corresponding to the third step of thermochemical growth of iron borides proposed by Martini et al. (2004) [38]. The SEM images, Fig. 2 (a) and (d), confirm the $\mathrm{Fe}_{2} \mathrm{~B}$ single-phase layer for the 1.21B sample. The outermost $\mathrm{FeB}$ and the inner $\mathrm{Fe}_{2} \mathrm{~B}$ layers in the 8.26B specimen are visible in SEM images Fig. 2 (c) and (f). Although the FeB phase peaks appeared in the XRD pattern (Fig. 1), the SEM images, in Fig. 2 (b) and (e), do not show the presence of FeB in the 4.35B sample, which indicates that the FeB layer on this sample was not continuous, but a series of FeB crystals dispersed in the $\mathrm{Fe}_{2} \mathrm{~B}$ phase.

Also, cracks are present in the three conditions, the cracks in the $8.26 \mathrm{~B}$ specimen outnumber the other two boron amounts most likely due to the difference in thermal expansion coefficients between $\mathrm{FeB}$ and $\mathrm{Fe}_{2} \mathrm{~B}$ phases $\left(\mathrm{a}_{\mathrm{FeB}}=23 \times 10^{-3} /{ }^{\circ} \mathrm{C}, \mathrm{a}_{\mathrm{Fe} 2 \mathrm{~B}}=7.85 \times 10^{-3} /{ }^{\circ} \mathrm{C}\right)[1]$.

The thicknesses of the $1.21 \mathrm{~B}$ and $4.35 \mathrm{~B}$ samples are $39 \mu \mathrm{m}$ and $52 \mu \mathrm{m}$, respectively (Table 2 ). While the 8.26B sample showed a total thickness of $62 \mu \mathrm{m}$, being $11 \mu \mathrm{m}$ of the outermost FeB layer.

Table 2

Average thickness, hardness, and reduced elastic modulus of the borided samples.

\begin{tabular}{|lllll|}
\hline Sample & Phases & Thickness $(\boldsymbol{\mu m})$ & $\begin{array}{l}\text { Hardness }-\mathrm{H} \\
(\mathrm{GPa})\end{array}$ & $\begin{array}{l}\text { Reduced Young's Modulus - E } \\
(\mathrm{GPa})\end{array}$ \\
\hline $1.21 \mathrm{~B}$ & $\mathrm{Fe}_{2} \mathrm{~B}$ & $39 \pm 2$ & $12.6 \pm 0.7$ & $318 \pm 4$ \\
\hline $4.35 \mathrm{~B}$ & $\begin{array}{l}\mathrm{FeB}+ \\
\mathrm{Fe}_{2} \mathrm{~B}\end{array}$ & $52 \pm 2$ & $13.7 \pm 1.0$ & $319 \pm 4$ \\
\hline $8.26 \mathrm{~B}$ & $\begin{array}{l}\mathrm{FeB}+ \\
\mathrm{Fe}_{2} \mathrm{~B}\end{array}$ & $\begin{array}{l}11 \pm 2(\mathrm{FeB}) \\
62 \pm 2(\mathrm{FeB}+\end{array}$ & $16.7 \pm 1.7$ & $344 \pm 6$ \\
& & $\left.\mathrm{Fe}_{2} \mathrm{~B}\right)$ & \\
\hline $\begin{array}{l}\mathrm{AlSI} \\
4140\end{array}$ & - & - & $3.5 \pm 0.2$ & $222 \pm 4$ \\
\hline
\end{tabular}

The borided layers (Table 2) were three to four times harder than the untreated AISI 4140 steel substrate, which presents a hardness of $3.5 \mathrm{GPa}$. The surface hardness increased with the boron amount since the $1.21 \mathrm{~B}$ sample showed the lowest $(1282 \mathrm{HV}$ or $12.6 \mathrm{GPa}$ ) while the $8.26 \mathrm{~B}$ sample showed the highest surface hardness $(1705 \mathrm{HV}$ or $16.7 \mathrm{GPa}$ ). The higher surface hardness of the $8.26 \mathrm{~B}$ specimen is related to the higher hardness of the outer $\mathrm{FeB}$ phase. The 4.35B sample showed an intermediate hardness (1395 $\mathrm{HV}$ or $13.7 \mathrm{GPa}$ ), closer to the $1.21 \mathrm{~B}$ sample since the harder FeB layer was not homogeneous in the 4.35B sample. 
The reduced elastic moduli (Table 2 ) significantly differ among the samples. All borided samples presented a higher reduced elastic modulus than the untreated steel substrate (222 GPa). The boron diffusion in the material's crystal lattice leads to higher surface rigidity [45]. The dual-phase boride layer on the 8.26B sample showed the highest modulus ( $344 \mathrm{GPa}$ ) since the outer FeB layer, with a massive amount of boron, results in a higher surface rigidity. The 1.21B and 4.35B samples showed similar elastic modulus (318 and $319 \mathrm{GPa}$, respectively) to the one found by da Costa Aichholz et al. (2018) [46] in samples with the $\mathrm{Fe}_{2} \mathrm{~B}$ phase (313 GPa).

\subsection{Adhesion}

The scratch tests were performed; consequently, the failure modes were identified, and the critical loads were assigned for each boriding condition. SEM images were taken to accurately determine the critical loads to reveal the scratch groove details, as shown in Fig. 3 . The critical loads were correlated to the defined and repeated failure mechanisms, as shown in Table 3. Examining the scratch grooves, in Fig. 3 , three failure modes can be identified in the borided cases: arc tensile cracks, forward chevron tensile cracks, and chipping. The first failure to occur is arc tensile cracking, which occurs due to a tensile stress field generated behind the indenter caused by its penetration [47]. The arc tensile cracks were observed at $37 \mathrm{~N}, 33 \mathrm{~N}$, and $7 \mathrm{~N}$, for the 1.21B, 4.35B, and 8.26B samples, respectively. Arc tensile cracks correlate with Young's moduli (E) difference between the borided layer and steel substrate (Table 2). The borided layer of the 8.26B sample showed a much higher surface reduced Young's modulus due to the FeB layer, which results in a smaller capacity to deform under tensile stresses, consequently leading to the lowest critical load for this failure mode.

Table 3

Critical loads for the failure modes of the borided samples.

\begin{tabular}{|lll|}
\hline Sample & Failure modes & Critical damage load $(\mathbf{N})$ \\
\hline 1.21B & Arc Tensile Cracks & 37 \\
& Forward Chevron Tensile Cracks & 37 \\
& Chipping & 145 \\
\hline \multirow{2}{*}{ 4.35B } & Arc Tensile Cracks & 33 \\
& Forward Chevron Tensile Cracks & 44 \\
& Chipping & 146 \\
\hline \multirow{2}{*}{$8.26 \mathrm{~B}$} & Arc Tensile Cracks & 7 \\
& Forward Chevron Tensile Cracks & 53 \\
& Chipping & 126 \\
\hline
\end{tabular}

Furthermore, the borided layers present different fracture toughness; the FeB phase has almost a quarter of the fracture toughness of the $\mathrm{Fe}_{2} \mathrm{~B}$ phase [48], which directly impacts the material's ability to deform without the formation of cracks. Then, as the scratch test progresses, forward chevron tensile cracks 
form on the borided samples, initiating inside the scratch groove and propagating away from it. This failure mechanism occurs due to the plastic deformation of the substrate [49]. Its onset seems to depend mainly on the borided layer's thickness since thinner layers tend to have less resistance to accommodate such deformation; consequently, it takes place at $37 \mathrm{~N}, 44 \mathrm{~N}$, and $53 \mathrm{~N}$ for the 1.21B, 4.35B, and 8.26B samples, respectively. Finally, the borided layer's chipping takes place at $145 \mathrm{~N}, 146 \mathrm{~N}$, and $126 \mathrm{~N}$ for the $1.21 \mathrm{~B}, 4.35 \mathrm{~B}$, and $8.26 \mathrm{~B}$ specimens. Notice that the borided layer with the FeB phase, namely sample $8.26 \mathrm{~B}$, shows lower chipping critical load, revealing the fragile nature of the FeB layer.

\subsection{Wear behavior}

Figure 4 shows the CoF behavior versus the sliding distance. The CoF behavior of the borided cases shows two stages: running-in and steady-state. The running stage varied among the borided cases; the shortest running-in corresponds to the $1.21 \mathrm{~B}$ sample, and the longest to the $8.26 \mathrm{~B}$ sample. The variation in the running-in is due to the difference in hardness among the samples since the running-in occurs when the asperities of the $\mathrm{Al}_{2} \mathrm{O}_{3}$ ball and the tested borided surfaces are deformed, and the surfaces are brought together. Then, the 1.21B sample has the lowest surface hardness, which resulted in faster deformation of the surface by the alumina counterpart, therefore the shorter running-in. In contrast, the 8.26B sample, with the higher hardness, exhibited more resistance to the asperity's deformation process, and consequently, a longer running-in is observed. In contrast, the steady-state period showed no difference among the three borided cases, and small fluctuations are related to oxide formation and its breakage [50], as well as material removal and formation of debris.

The optical profiler images and cross-sectional views of the tracks (Fig. 5) were used to obtain the total volumetric wear $(\mathrm{V})$ and then the specific wear rate $(\mathrm{K})$ of the tested samples (Table 4). The wear tracks did not exceed the thickness of the $\mathrm{Fe}_{2} \mathrm{~B}$ (for the 1.21B and 4.35B samples) and $\mathrm{FeB}$ (for the 8.26B sample) layers. Since borided layers are useful for tribological applications if $k<10^{-6} \mathrm{~mm}^{3} / \mathrm{Nm}$ [21], the samples of the three conditions presented mild wear. The 1.21B sample, with the higher wear rate $(\mathrm{k}=1.3$ $\left.x 10^{-6} \mathrm{~mm}^{3} / \mathrm{Nm}\right)$, presented the widest wear track, Fig. $5(\mathrm{a})$ and (b), with a lateral agglomeration of material (tribofilms and smearing). The wear track of the 4.35B sample ( $\left.\mathrm{k}=1.1 \times 10^{-6} \mathrm{~mm}^{3} / \mathrm{Nm}\right)$, Fig. 5 (c) and (d), is narrower and has a significant material agglomeration, mostly at the sides of the track. The $8.26 \mathrm{~B}$ sample had the lowest wear rate among the samples $\left(\mathrm{k}=0.9 \times 10^{-6} \mathrm{~mm}^{3} / \mathrm{Nm}\right)$, and the narrowest wear track, as observed in Fig. $5(\mathrm{e})$ and (f), which is expected, since the wear rate is usually related to the hardness of the material [51, 52], and sample 8.26B, containing the FeB phase, showed the higher surfaces hardness among the studied conditions. Previous results also showed higher wear abrasion resistance of the $\mathrm{FeB}$ phase over the $\mathrm{Fe}_{2} \mathrm{~B}$ phase [53]. 
Table 4

Coefficient of friction (CoF), wear volumes, and specific wear rate of the borided samples.

\begin{tabular}{|lll|}
\hline Sample & $\begin{array}{l}\text { Wear volume of the borided disk } \\
\text { specimens }(\mathrm{V}) \mathbf{1 0}^{-\mathbf{3}}\left[\mathrm{mm}^{\mathbf{3}}\right]\end{array}$ & $\begin{array}{l}\text { Specific wear rate of borided disk specimens } \\
(\mathbf{k}), \mathbf{1 0}^{-6}\left[\mathrm{~mm}^{\mathbf{3}} / \mathrm{Nm}\right]\end{array}$ \\
\hline $1.21 \mathrm{~B}$ & $12.5 \pm 1.6$ & $1.3 \pm 0.2$ \\
\hline 4.35B & $11.1 \pm 1.8$ & $1.1 \pm 0.2$ \\
\hline 8.26B & $9.4 \pm 1.4$ & $0.9 \pm 0.1$ \\
\hline
\end{tabular}

The main wear mechanisms of the borided specimens are shown in Fig. 6 (a), (c), and (e). The first wear mechanism is grooving, resulting from the plowing effect due to hard particles, which are removed from the borided surface during the tests, and act as an abrasive surface, as previously observed [54], resulting in micro-abrasion of the borided layers. It can be identified as scratches parallel to the sliding direction. This mechanism is more severe on the surface of the 1.21B sample but is also present in the $4.35 \mathrm{~B}$ sample, as revealed in Fig. 6 (a) and (c).

The 1.21B sample showed higher material removal during the tests, resulting in higher grooving levels on its surface, consequently a higher wear rate. The $8.26 \mathrm{~B}$ sample has a thicker borided layer than the other two samples (Table 2), which decreases the wear loss, as supported by previous results [54-56]. The 8.26B sample surface has a large portion of polished regions visible in smooth areas and occurs due to lower levels of material removal, with no visible scratching [21]. The higher surface hardness improved resistance to the plowing effect, which was also observed previously [54].

The repeated loading and unloading of the surfaces can lead to surface fatigue [21], which results in flaking and pitting of the surface, the latter occurring when portions of material are torn out, creating irregular craters on the surface namely pits. Although the 8.26B sample has the lowest wear rate, its very hard surface could not sustain large plastic deformation, leading to larger flaking of the surface, followed by pitting, as can be seen in Fig. 6 (e). Tribofilms can be observed at the surface of the samples. These films result from material agglomeration after debris adhere and cluster due to mechanical contacts at the surface, as previously observed $[21,51]$. Heavily oxidized tribofilms, identified as smearing, can be seen inside and on the sides of the wear tracks, mostly in the $8.26 \mathrm{~B}$ specimen.

The aspect of the $\mathrm{Al}_{2} \mathrm{O}_{3}$ balls after sliding is shown in Fig. 7. The images reveal that the sliding contact resulted in the flattening of the $\mathrm{Al}_{2} \mathrm{O}_{3}$ balls. The wear scar of the alumina ball against 1.21B samples, Fig. 7 (a), shows plowing lines. It indicates grooving as the main wear mechanism, which occurred due to the three-body abrasive wear on the ball and disk, resulting in higher wear of 1.21B disk (borided specimen) (Table 4). The wear scar of the alumina ball against the 4.35B sample, Fig. 7 (b), shows less grooving than for 1.21B-ball, which indicates a lower formation of debris and less borided specimen wear (Table 4). In the case of the alumina ball against the $8.26 \mathrm{~B}$ samples, the wear scar was smooth, with no grooving lines. The higher surface hardness of the $8.26 \mathrm{~B}$ sample resulted in higher alumina's ball wear. 
The EDS analysis of the wear scars of the alumina balls shows material adhesion, Fig. 7 (b), (d), and (f). they indicate the presence of mainly iron-oxides. The iron-oxides found in the pair 8.26B sample-ball (Fig. 6 (f) and 7 (f)), in higher amount, may have reduced the wear in the borided sample. Because the ironoxides films can act as a lubricant, reducing the CoF; consequently, mitigating wear [21,51]. On the other hand, it was observed high levels of flaking and pitting of its surface, probably due to the high brittleness of the FeB phase, resulting in less surface resistance to fatigue.

\section{Conclusions}

- The mixtures manufactured in this work can be easily reproduced, and new mixtures can be easily obtained in an industrial environment. Furthermore, by controlling the amount of boron in the mixture, the microstructure resulting from the boriding process can also be manipulated.

- $A \mathrm{Fe}_{2} \mathrm{~B}$ single-phase was obtained by boriding with $1.21 \mathrm{wt} \%$ of $\mathrm{B}$, and the FeB phase appeared in both $4.35 \mathrm{~B}$ and $8.26 \mathrm{~B}$ samples. However, the FeB phase on the 4.35B sample was not homogeneous, and this sample showed similar surface properties to the $1.21 \mathrm{~B}$ sample.

- The scratch test revealed the same failure modes regardless of the boron amount: arc tensile cracks, forward chevron tensile cracks, and chipping. On the other hand, the critical loads are different, revealing that microstructure and, consequently, surface hardness, Young's modulus, thickness affect the critical load. The $8.26 \mathrm{wt} \% \mathrm{~B}$ specimens have the most fragile behavior due to the outer FeB phase.

- The sliding contact between the borided cases and alumina balls generated abrasive wear. The average friction coefficients are practically the same for the three borided specimens. Although the running-in stage of the friction coefficient behavior is the longest for the $8.26 \mathrm{~B}$ specimen, which is related to the highest hardness of this borided condition, the higher the hardness, the more difficult is the breakage of asperities.

- The specific wear rate for the 8.26B sample was the lowest among the three investigated conditions due to its higher surface hardness and a larger amount of iron-oxides formation during the tribological tests. On the other hand, the FeB phase increases the brittleness of the borided case causing several different surface fatigue mechanisms.

\section{Declarations}

\section{Acknowledgments}

The authors would like to thank Fiven Brazil for supplying our work material and supporting this research.

\section{Funding}

This study was financed by CAPES (Finance Code 001) and FINEP agency under contract 01.10.0634. 


\section{Competing Interests}

The authors have no relevant financial or non-financial interests to disclose.

\section{Availability of data and material}

All data generated or analysed during this study are included in this published article (and its supplementary information files).

\section{Code availability}

Not applicable

\section{Ethics approval}

Not applicable

\section{Consent to participate}

Informed consent was obtained from all individual participants included in the study.

\section{Consent for publication}

The Authors hereby consent to publication of the Work in any and all JAMT publications.

\section{References}

1. Sinha AK (1991) Boriding (Boronizing) of Steels. ASM Handbook. Volume 4: Heat Treating. ASM International, Materials Park, Oh, USA, pp 978-1000

2. Yang $\mathrm{H}$, Wu X, Cao G, Yang Z (2016) Enhanced boronizing kinetics and high temperature wear resistance of $\mathrm{H} 13$ steel with boriding treatment assisted by air blast shot peening. Surface and Coatings Technology 307:506-516. https://doi.org/10.1016/j.surfcoat.2016.09.029

3. Martini C, Palombarini G, Poli G, Prandstraller D (2004) Sliding and abrasive wear behaviour of boride coatings. Wear 256:608-613. https://doi.org/10.1016/j.wear.2003.10.003

4. Keddam M, Makuch N, Boumaali B et al (2020) Liquid Boriding of Cp-Ti and Ti6Al4V Alloy: Characterization of Boride Layers and Tribological Properties. Surf Eng Appl Electrochem 56:348357. https://doi.org/10.3103/S1068375520030096

5. Belkin PN, Kusmanov SA (2019) Plasma Electrolytic Boriding of Steels and Titanium Alloys. Surf Eng Appl Electrochem 55:1-30. https://doi.org/10.3103/S106837551901006X

6. Yusuf Kayalı K (2021) Investigation of Wear Behavior and Diffusion Kinetic Values of Boronized Hardox-450 Steel. Protection of Metals and Physical Chemistry of Surfaces 57:1025-1033. https://doi.org/10.1134/S2070205121050129 
7. Morón RC, Hernández-Onofre I, Contla-Pacheco AD et al (2020) Friction and Reciprocating Wear Behavior of Borided AISI H13 Steel Under Dry and Lubricated Conditions. J Mater Eng Perform 29:4529-4540. https://doi.org/10.1007/s11665-020-04957-w

8. Yapici A, Aydin SE, Koc V et al (2019) Wear Behavior of Borided AISI D2 Steel under Linear Reciprocating Sliding Conditions. Protection of Metals and Physical Chemistry of Surfaces 55:341351. https://doi.org/10.1134/S207020511902028X

9. Campos-Silva I, Vega-Morón RC, Reséndiz-Calderón CD et al (2019) Dry Sliding Wear Resistance of Cobalt Boride Coatings Formed on ASTM F1537 Alloy. J Mater Eng Perform 28:2399-2410. https://doi.org/10.1007/s11665-019-04012-3

10. Krelling AP, Milan JCG, da Costa CE (2015) Tribological behaviour of borided H13 steel with different boriding agents. Surf Eng 31:581-587. https://doi.org/10.1179/1743294414Y.0000000423

11. Kusmanov SA, Tambovskii IV, Kusmanova IA, Belkin PN (2021) Improving the Wear Resistance of VT22 Titanium Alloy by Anodic Plasma Electrolytic Boriding. Surf Eng Appl Electrochem 57:419424. https://doi.org/10.3103/S1068375521040098

12. Khater MA, Bouaziz SA, Garrido MA, Poza P (2021) Mechanical and tribological behaviour of titanium boride coatings processed by thermochemicals treatments. Surf Eng 37:101-110. https://doi.org/10.1080/02670844.2020.1763765

13. Sezgin CT, Hayat F (2022) The effects of boriding process on tribological properties and corrosive behavior of a novel high manganese steel. J Mater Process Technol 300:117421. https://doi.org/10.1016/j.jmatprotec.2021.117421

14. Li P, Liu D, Bao W et al (2018) Surface characterization and diffusion model of pack borided TB2 titanium alloy. Ceram Int 44:18429-18437. https://doi.org/10.1016/j.ceramint.2018.07.060

15. Liu D, Duan Y, Bao W, Peng M (2020) Characterization and growth kinetics of boride layers on Ti5Mo-5V-8Cr-3Al alloy by pack boriding with CeO2. Mater Charact 164:110362. https://doi.org/10.1016/j.matchar.2020.110362

16. Peng M-J, Duan Y-H, Ma L-S, Shu B-P (2018) Characteristics of surface layers on Ti6Al4V alloy borided with $\mathrm{CeO} 2$ near the transition temperature. J Alloys Compd 769:1-9. https://doi.org/10.1016/j.jallcom.2018.07.365

17. Duan Y, Wang X, Liu D et al (2020) Characteristics, wear and corrosion properties of borided pure titanium by pack boriding near $a \rightarrow \beta$ phase transition temperature. Ceram Int 46:16380-16387. https://doi.org/10.1016/j.ceramint.2020.03.197

18. Duan Y, Li P, Chen Z et al (2018) Surface evolution and growth kinetics of Ti6Al4V alloy in pack boriding. J Alloys Compd 742:690-701. https://doi.org/10.1016/j.jallcom.2018.01.383

19. Kara G, Purcek G (2018) Growth kinetics and mechanical characterization of boride layers formed on $\beta$-type Ti-45Nb alloy. Surf Coat Technol 352:201-212. https://doi.org/10.1016/j.surfcoat.2018.07.085

20. Campos-Silva I, Palomar-Pardavé M, Pérez Pastén-Borja R et al (2018) Tribocorrosion and cytotoxicity of FeB-Fe2B layers on AISI 316 L steel. Surface and Coatings Technology 349:986-997. 
https://doi.org/10.1016/j.surfcoat.2018.05.085

21. García-León RA, Martínez-Trinidad J, Campos-Silva I et al (2021) Wear maps of borided AISI 316L steel under ball-on-flat dry sliding conditions. Mater Lett 282:128842.

https://doi.org/10.1016/j.matlet.2020.128842

22. Haftlang F, Habibolahzadeh A (2020) Characterization and tribological performance of TiB2/TiB composite coatings fabricated by duplex surface treatment. Mater Lett 281:128626.

https://doi.org/10.1016/j.matlet.2020.128626

23. Hernández-Ramírez EJ, Guevara-Morales A, Figueroa-López U, Campos-Silva I (2020) Wear resistance of diffusion annealed borided AISI 1018 steel. Mater Lett 277:128297. https://doi.org/10.1016/j.matlet.2020.128297

24. Türkmen I, Yalamaç E, Keddam M (2019) Investigation of tribological behaviour and diffusion model of Fe2B layer formed by pack-boriding on SAE 1020 steel. Surface and Coatings Technology 377:124888. https://doi.org/10.1016/j.surfcoat.2019.08.017

25. Panda JN, Wong BC, Medvedovski E, Egberts P (2021) Enhancement of tribo-corrosion performance of carbon steel through boronizing and BN-based coatings. Tribol Int 153:106666. https://doi.org/10.1016/j.triboint.2020.106666

26. Türkmen I, Yalamaç E (2018) Growth of the Fe2B layer on SAE 1020 steel employed a boron source of H3BO3 during the powder-pack boriding method. J Alloys Compd 744:658-666. https://doi.org/10.1016/j.jallcom.2018.02.118

27. Meneses-Amador A, Sandoval-Juárez D, Rodríguez-Castro GA et al (2018) Contact fatigue performance of cobalt boride coatings. Surface and Coatings Technology 353:346-354. https://doi.org/10.1016/j.surfcoat.2018.07.104

28. Reséndiz-Calderón CD, Farfan-Cabrera LI, Oseguera-Peña JE, Rodríguez-Castro GA (2020) Wear and friction of boride layer in CoCrMo alloy under different micro-abrasion modes (rolling and grooving abrasion). Mater Lett 279:128500. https://doi.org/10.1016/j.matlet.2020.128500

29. Lindner T, Löbel M, Sattler B, Lampke T (2019) Surface hardening of FCC phase high-entropy alloy system by powder-pack boriding. Surface and Coatings Technology 371:389-394. https://doi.org/10.1016/j.surfcoat.2018.10.017

30. Delgado-Brito AM, López-Suero D, Ruiz-Ríos A et al (2019) Effect of the diffusion annealing process in the indentation properties of cobalt boride layer. Ceram Int 45:7767-7777. https://doi.org/10.1016/j.ceramint.2019.01.081

31. Campos-Silva I, Delgado-Brito AM, Oseguera-Peña J et al (2019) Tribocorrosion resistance of borided ASTM F1537 alloy. Surface and Coatings Technology 375:810-823. https://doi.org/10.1016/j.surfcoat.2019.06.098

32. Campos-Silva I, Contla-Pacheco AD, Ruiz-Rios A et al (2018) Effects of scratch tests on the adhesive and cohesive properties of borided Inconel 718 superalloy. Surface and Coatings Technology 349:917-927. https://doi.org/10.1016/j.surfcoat.2018.05.086 
33. Lindner T, Löbel M, Hunger R et al (2020) Boriding of HVOF-sprayed Inconel 625 coatings. Surface and Coatings Technology 404:126456. https://doi.org/10.1016/j.surfcoat.2020.126456

34. Campos-Silva I, Contla-Pacheco AD, Figueroa-López U et al (2019) Sliding wear resistance of nickel boride layers on an Inconel 718 superalloy. Surface and Coatings Technology 378:124862. https://doi.org/10.1016/j.surfcoat.2019.06.099

35. Kul M, Oskay KO, Temizkan A et al (2016) Effect of boronizing composition on boride layer of boronized GGG-60 ductile cast iron. Vacuum 126:80-83. https://doi.org/10.1016/j.vacuum.2016.01.021

36. Arulbrittoraj A, Duraiselvam M, Padmanabhan P (2017) Sliding wear of AISI1040 steel at different thermo chemical surface treated conditions. Int J Surf Sci Eng 11:531. https://doi.org/10.1504/IJSURFSE.2017.10010005

37. Spence TW, Makhlouf MM (2005) Characterization of the operative mechanism in potassium fluoborate activated pack boriding of steels. J Mater Process Technol 168:127-136. https://doi.org/10.1016/j.jmatprotec.2004.10.015

38. Martini C, Palombarini G, Carbucicchio M (2004) Mechanism of thermochemical growth of iron borides on iron. J Mater Sci 39:933-937. https://doi.org/10.1023/B:JMSC.0000012924.74578.87

39. YU L, CHEN X, KHOR K, SUNDARARAJAN G (2005) FeB/FeB phase transformation during SPS packboriding: Boride layer growth kinetics. Acta Mater 53:2361-2368. https://doi.org/10.1016/j.actamat.2005.01.043

40. Oliver WC, Pharr GM (1992) An improved technique for determining hardness and elastic modulus using load and displacement sensing indentation experiments. J Mater Res 7:1564-1583. https://doi.org/10.1557/jmr.1992.1564

41. International A (2015) ASTM E2546-15 - Standard Practice for Instrumented Indentation Testing. ASTM Book of Standards 1:1-23

42. International A (2010) ASTM C1624 - 05 Standard Test Method for Adhesion Strength and Mechanical Failure Modes of Ceramic Coatings by Quantitative Single Point Scratch Testing.ASTM Book of Standards $1-28$

43. International A (2017) ASTM G99-17 - Standard Test Method for Wear Testing with a Pin-on-Disk Apparatus. 05:1-6

44. Santana DA, Koga GY, Wolf W et al (2020) Wear-resistant boride reinforced steel coatings produced by non-vacuum electron beam cladding. Surface and Coatings Technology 386:125466. https://doi.org/10.1016/j.surfcoat.2020.125466

45. Meneses-Amador A, Blancas-Pérez D, Corpus-Mejía R et al (2018) Adhesive and Cohesive Strength in FeB/Fe2B Systems. J Mater Eng Perform 27:2089-2098. https://doi.org/10.1007/s11665-018-3150z

46. da Costa Aichholz SA, Sostag Meruvia M, Soares Júnior PC, Torres RD (2018) Tribocorrosion behavior of boronized AISI 4140 steel. Surface and Coatings Technology 352:265-272. https://doi.org/10.1016/j.surfcoat.2018.07.101 
47. Meneses-Amador A, Jiménez-Tinoco LF, Reséndiz-Calderon CD et al (2015) Numerical evaluation of scratch tests on boride layers. Surface and Coatings Technology 284:182-191. https://doi.org/10.1016/j.surfcoat.2015.06.088

48. Campos-Silva IE, Rodríguez-Castro GA (2015) Boriding to improve the mechanical properties and corrosion resistance of steels. Woodhead Publishing Limited

49. Rodríguez-Castro GA, Vega-Morón RC, Meneses-Amador A et al (2016) Multi-pass scratch test behavior of AISI 316L borided steel. Surface and Coatings Technology 307:491-499. https://doi.org/10.1016/j.surfcoat.2016.09.017

50. Erdogan A, Kursuncu B, Günen A et al (2020) A new approach to sintering and boriding of steels "Boro-sintering": Formation, microstructure and wear behaviors. Surface and Coatings Technology 386. https://doi.org/10.1016/j.surfcoat.2020.125482

51. García-León RA, Martínez-Trinidad J, Zepeda-Bautista R et al (2021) Dry sliding wear test on borided AISI 316L stainless steel under ball-on-flat configuration: A statistical analysis. Tribol Int 157:106885. https://doi.org/10.1016/j.triboint.2021.106885

52. Fernández-Valdés D, Meneses-Amador A, López-Liévano A, Ocampo-Ramírez A (2021) Sliding wear analysis in borided AISI 316L steels. Mater Lett 285:129138. https://doi.org/10.1016/j.matlet.2020.129138

53. Reséndiz-Calderon CD, Rodríguez-Castro GA, Meneses-Amador A et al (2017) Micro-Abrasion Wear Resistance of Borided 316L Stainless Steel and AISI 1018 Steel. J Mater Eng Perform 26:55995609. https://doi.org/10.1007/s11665-017-3004-0

54. Ulutan M, Celik ON, Gasan H, Er U (2010) Effect of Different Surface Treatment Methods on the Friction and Wear Behavior of AISI 4140 Steel. Journal of Materials Science \& Technology 26:251257. https://doi.org/10.1016/S1005-0302(10)60042-4

55. Meriç C, Sahin S, Backir B, Koksal NS (2006) Investigation of the boronizing effect on the abrasive wear behavior in cast irons. Mater Design 27:751-757. https://doi.org/10.1016/j.matdes.2005.01.018

56. Er U, Par B (2006) Wear of plowshare components in SAE 950C steel surface hardened by powder boriding. Wear 261:251-255. https://doi.org/10.1016/j.wear.2005.10.003

\section{Figures}




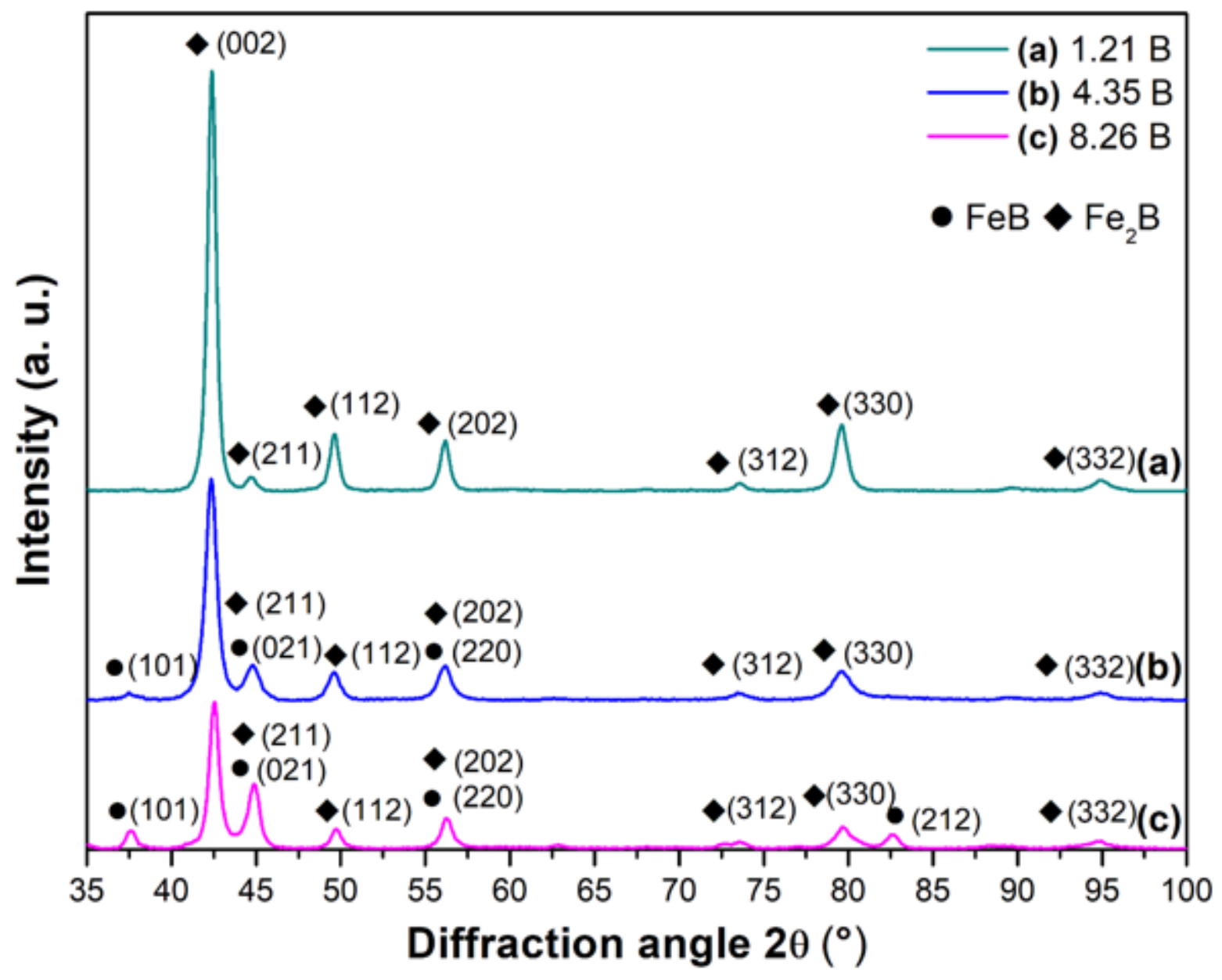

Figure 1

XRD patterns of boride samples: (a) 1.21B, (b) 4.35B, and (c) 8.26B. 


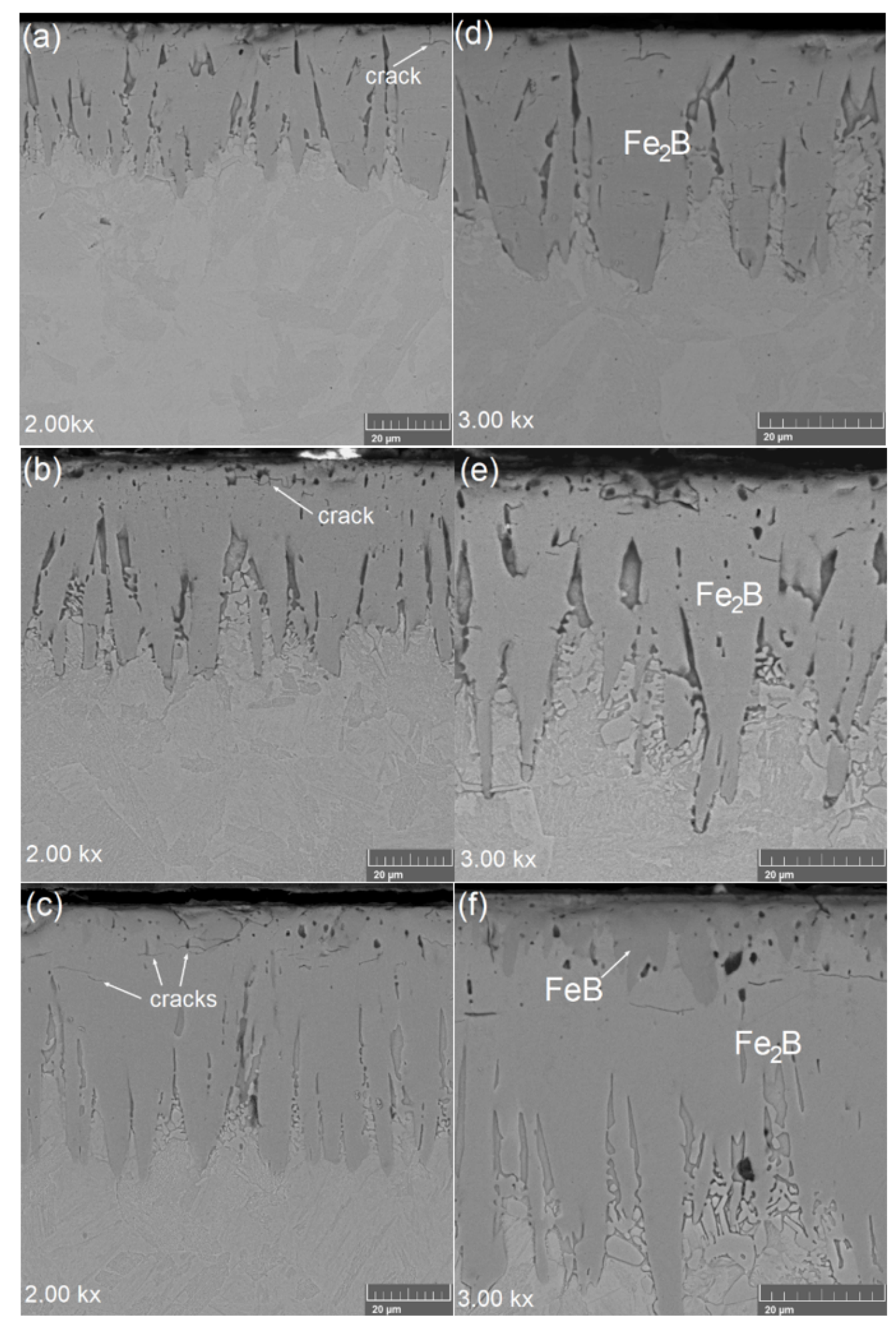

\section{Figure 2}

SEM cross-section images of borided samples: (a, d) 1.21B, (b, e) 4.35B, and (c, f) 8.26B, etched with Nital $2 \%$. 

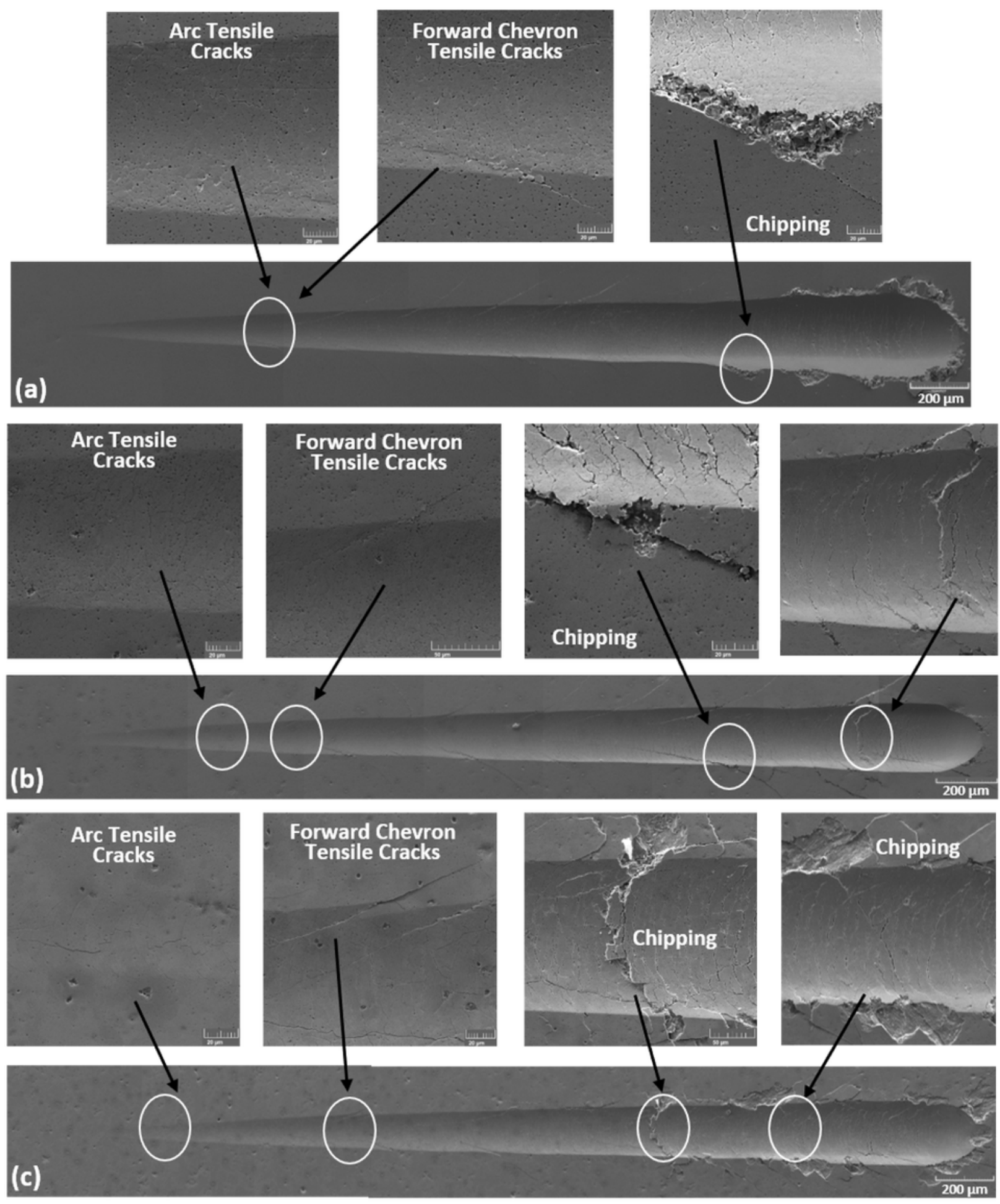

\section{Figure 3}

SEM images of the scratch grooves, with detail of the failure mechanisms: (a) 1.21B, (b) 4.35B, and (c) 8.26B samples. 


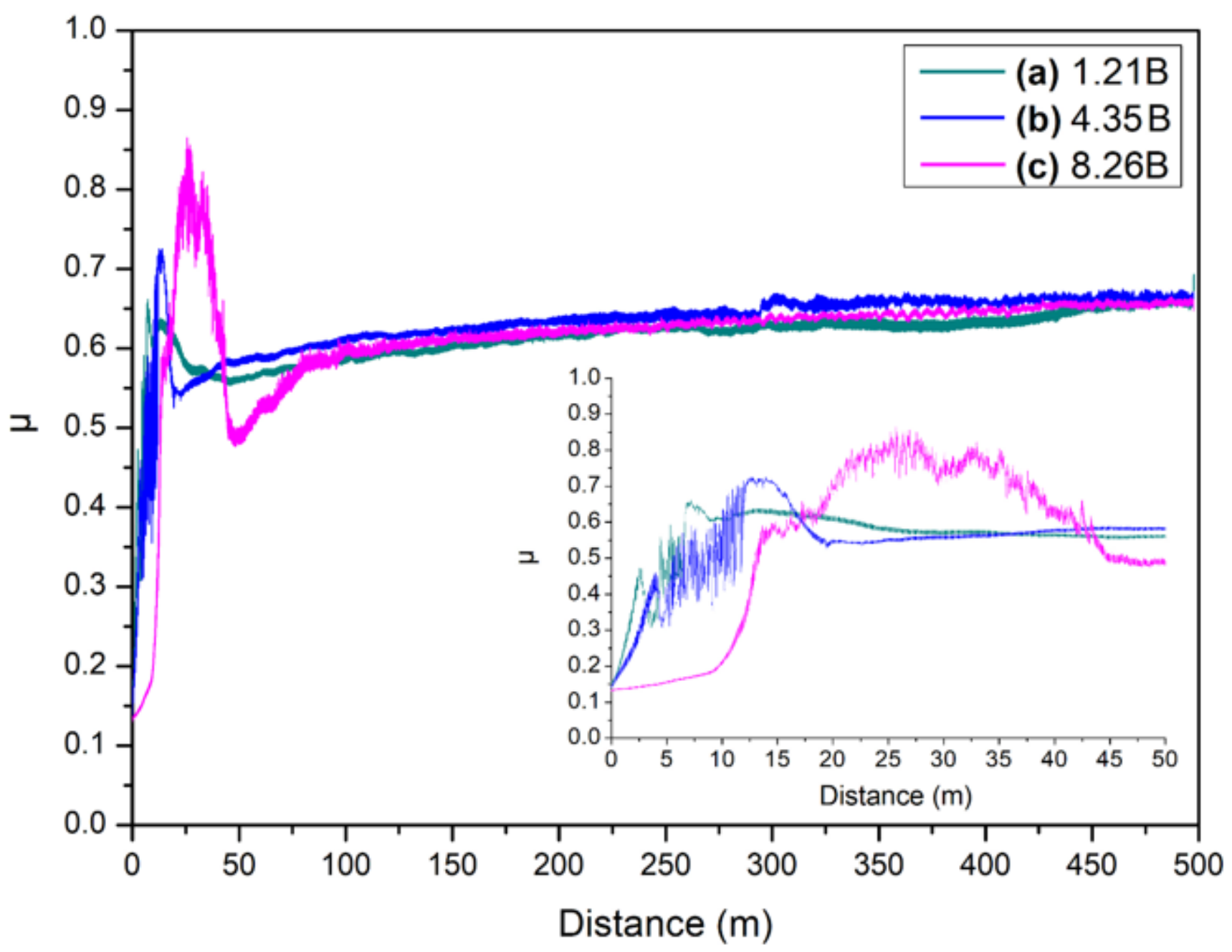

Figure 4

Friction behavior of the borided samples sliding against alumina balls. 
(a)
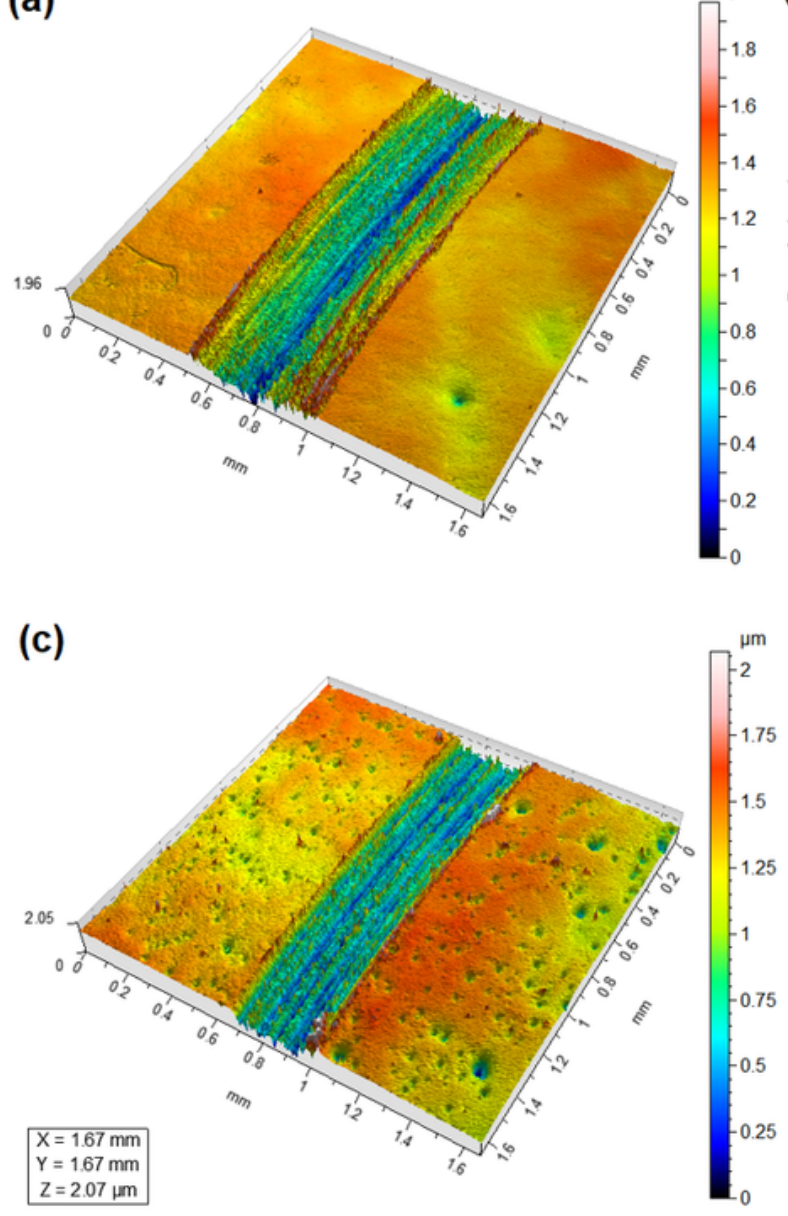

(e)

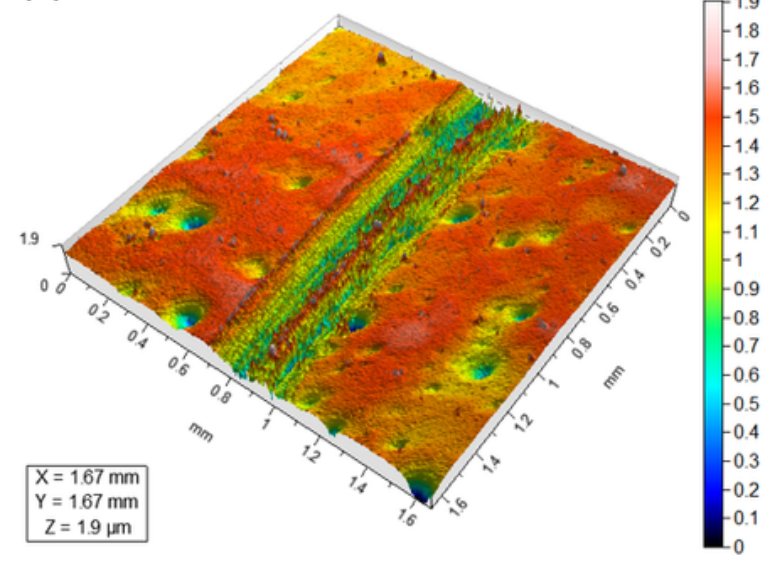

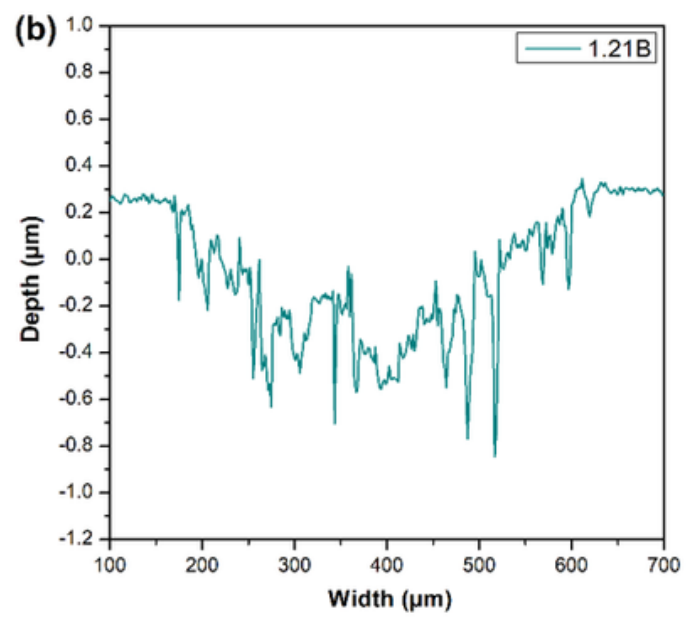
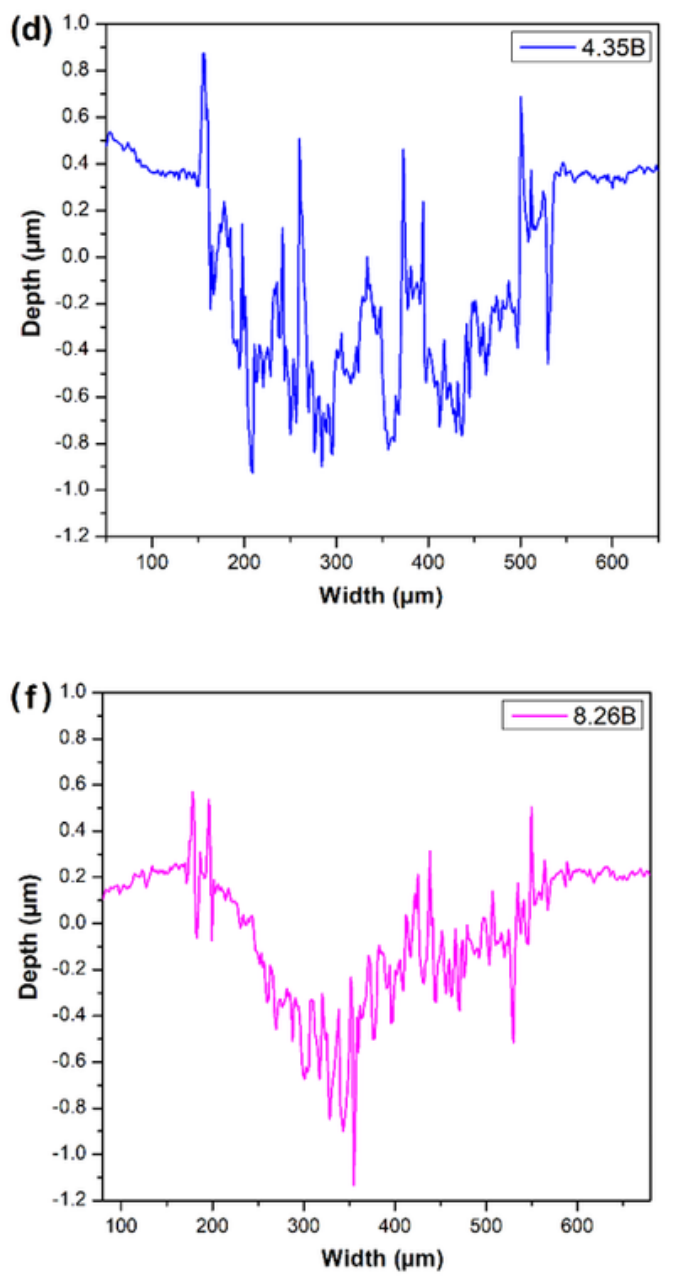

\section{Figure 5}

Optical profiler images and cross-sections of the wear tracks: $(a, b) 1.21 B,(c, d) 4.35 B$, and $(e, f) 8.26 B$ samples. 


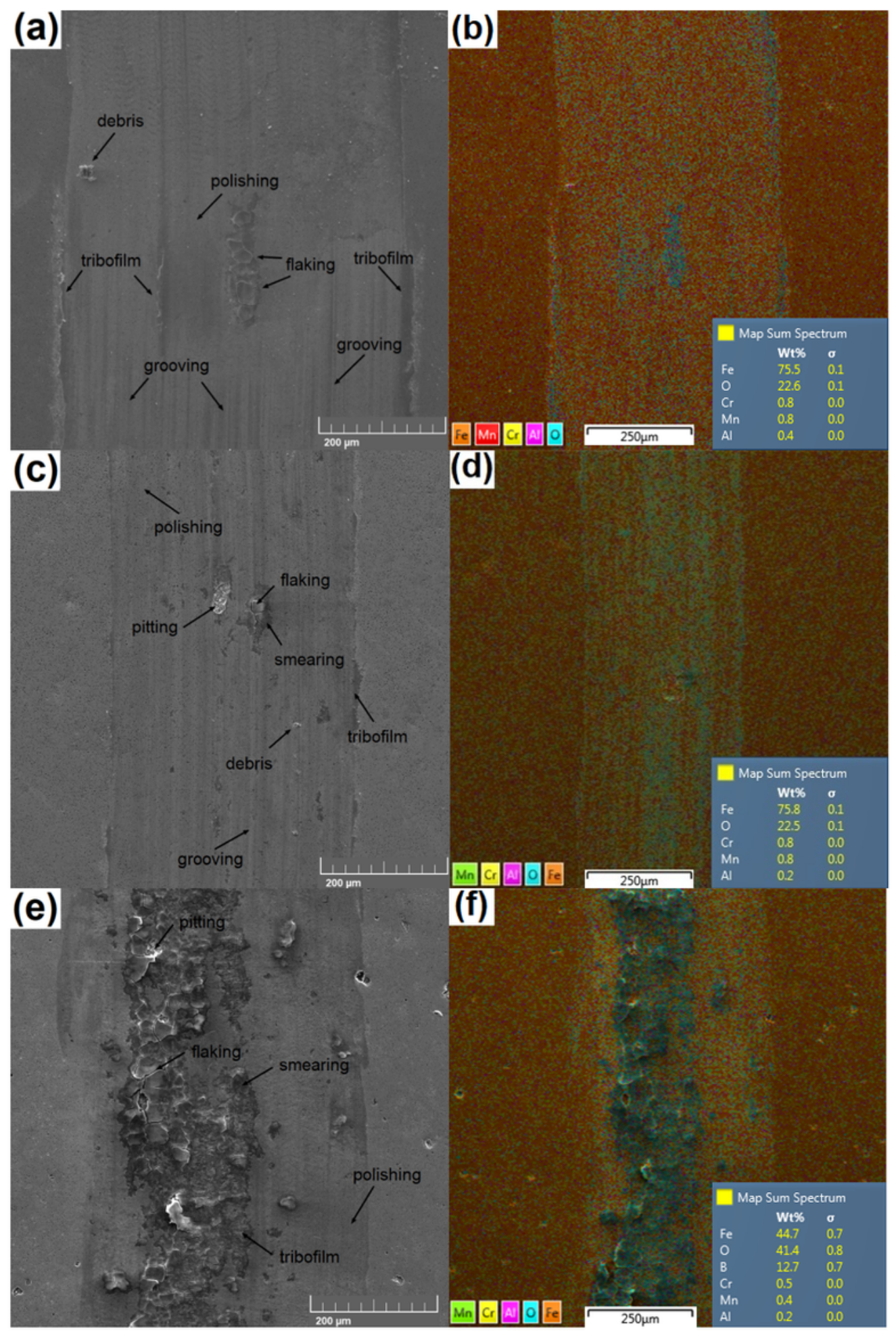

\section{Figure 6}

SEM images of the wear tracks and the corresponding EDS analysis: $(a, b) 1.21 B,(c, d) 4.35 B$, and (e, f) 8.26B samples. 


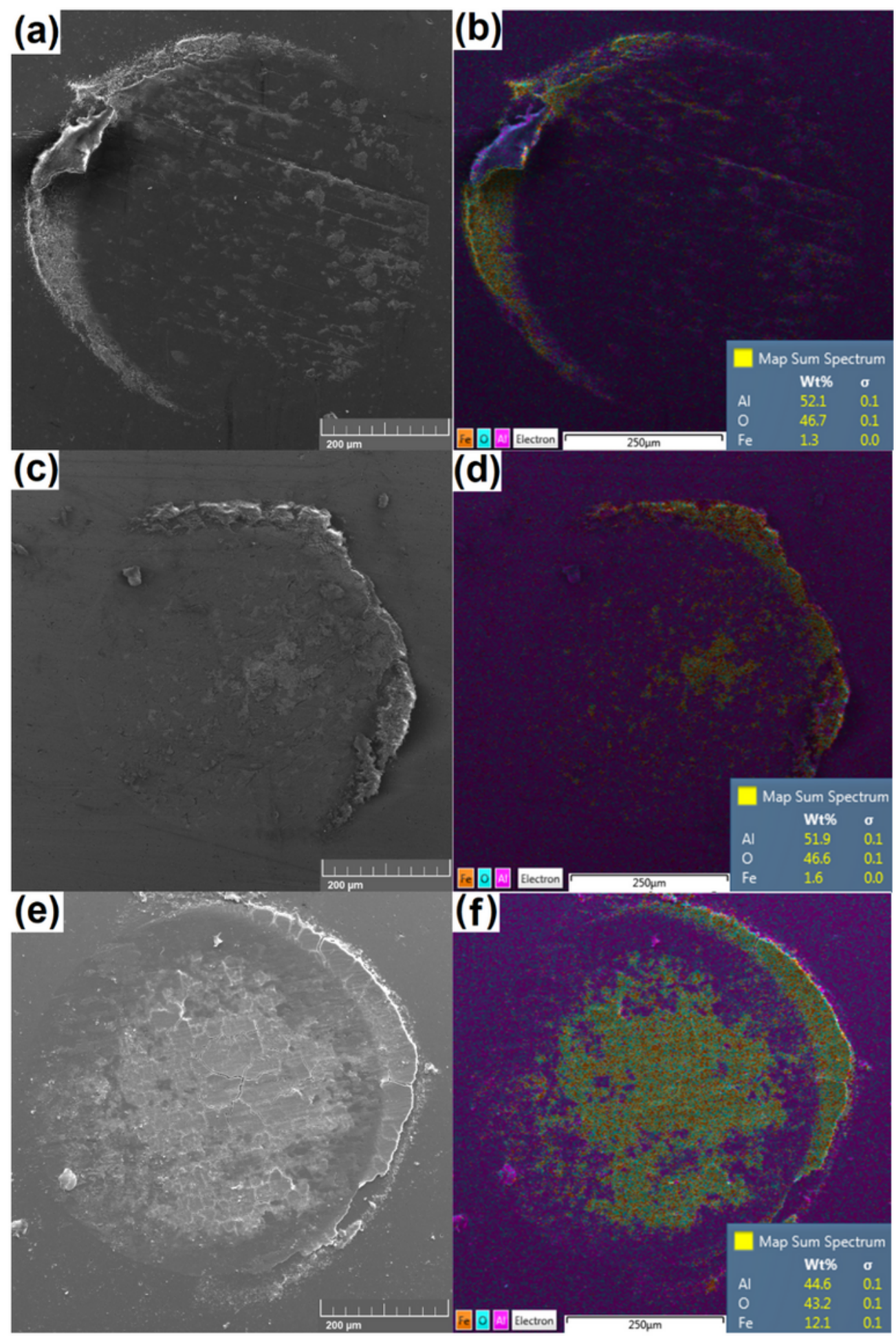

\section{Figure 7}

SEM images and EDS analysis of worn surfaces of $\mathrm{Al}_{2} \mathrm{O}_{3}$ balls against: $(a, b) 1.21 \mathrm{~B},(\mathrm{c}, \mathrm{d}) 4.35 \mathrm{~B}$, and $(\mathrm{e}$, f) $8.26 \mathrm{~B}$ samples. 